\title{
OPEN Author Correction: Weight loss and metabolic health effects from energy-restricted Mediterranean and Central-European diets in postmenopausal women: $A$ randomized controlled trial
}

\section{Joanna Bajerska, Agata Chmurzynska $\mathbb{D}^{\circ}$, Agata Muzsik, Patrycja Krzyżanowska, Edyta Mądry, Anna M. Malinowska \& Jarosław Walkowiak}

Correction to: Scientific Reports https://doi.org/10.1038/s41598-018-29495-3, published online 24 July 2018

The Acknowledgements section in this Article is incomplete.

"We thank the subjects for their committed participation in this study. The project was financed by a National Science Centre award based on decision number DEC-013/09/B/NZ9/02365."

should read:

"We thank the subjects for their committed participation in this study. The project was financed by a National Science Centre award based on decision number DEC-2013/09/B/NZ9/02365."

(i) Open Access This article is licensed under a Creative Commons Attribution 4.0 International License, which permits use, sharing, adaptation, distribution and reproduction in any medium or format, as long as you give appropriate credit to the original author(s) and the source, provide a link to the Creative Commons license, and indicate if changes were made. The images or other third party material in this article are included in the article's Creative Commons license, unless indicated otherwise in a credit line to the material. If material is not included in the article's Creative Commons license and your intended use is not permitted by statutory regulation or exceeds the permitted use, you will need to obtain permission directly from the copyright holder. To view a copy of this license, visit http://creativecommons.org/licenses/by/4.0/.

(c) The Author(s) 2019 